\title{
Steeping from green and black robusta coffee beans increase viability of Peripheral Blood Mononuclear Cells (PBMC) and salivary leukocytes which is induced by streptococcus mutans
}

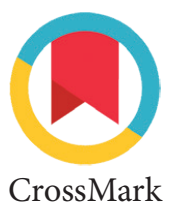

CrossMark

\author{
I-Dewa AR. Dewanti, ${ }^{1 *}$ Roedy Budirahardjo, ${ }^{2}$ Ristya WE. Yani, ${ }^{3}$ Pujiana E. Lestari, ${ }^{1}$ \\ Dyah Setyorini, ${ }^{2}$ Eri H. Jubhari, ${ }^{4}$ Sunlip Wibisono ${ }^{5}$
}

\section{Abstract}

Objective: Analyzing viability of PBMC and salivary leukocytes by steeping green coffee and black coffee seeds from Robusta coffee after induced with S. mutans.

Material and Methods:Blood and saliva of healthy peopleadded with histopaque centrifugation and suspended in RPMI 1640. The cells were placed in 24-well microtiter plate, treated according to group. The research groups: control: induced by $S$. mutans, black coffee $(2.5 \%, 5 \%$, $10 \%)$, Green coffee $(2.5 \%, 5 \%, 10 \%)$. All coffee groups, both PBMC and saliva groups were induced by $S$. mutans. Viability was stainted with Tripan Blue. Cells were counted under an inverted microscope with magnification 400 times from an average of 5 fields of view. The data obtained were ANOVA followed by LSD test.

Results:ANOVA and LSD analysis showed significant differences

$(0.01<p)$. The higher of concentration of Robusta coffee, the more cells that live. On the other hand, Green coffee increased the viability of PBMCand salivary leucocytes more than black coffee. Suspected, because antioxidant of the green coffee that more higher than black coffee, so it is better able to protect cells.

Conclusion: Steeping green and black coffee increaseviability of PBMC and leucocyteswhich is induced by $S$. mutans.
'Department of Biomedical Science, Faculty of Dentistry, Jember University, Jember, Indonesia

${ }^{2}$ Department of Pediatric, Faculty of Dentistry, Jember University, Jember, Indonesia

${ }^{3}$ Department of Public Dental Health, Faculty of Dentistry, Jember University, Jember, Indonesia

${ }^{4}$ Department of Prosthodontic, Faculty of Dentistry, Hasanudin University, Makasar, Indonesia ${ }^{5}$ Department of Statistic, Faculty of Economic and Business, Jember University, Jember, Indonesia

*Correspondence to: I-Dewa AR. Dewanti, Department of Biomedical Science, Faculty of Dentistry, Jember University, Jember, Indonesia idewadewanti@yahoo.com

Recieved: 11 February 2019

Revised: 29 March 2019

Accepted: 30 August 2019

Available online 1 December 2019
Keywords: Black coffee, Green coffee, Leucocytes, PBMC, Viability

Cite this Article: Dewanti IDAR, Budirahardjo R, Yani RWE, Lestari PE, Setyorini D, Jubhari EH, Wibisono S. 2019. Steeping from green and black robusta coffee beans increase viability of Peripheral Blood Mononuclear (ells (PBMC) and salivary leukocytes which is induced by streptococcus mutans. Journal of Dentomaxillofacial Science 4(3): 154-158. D0I: 10.15562/jdmfs.v4i3.799

\section{Introduction}

Coffee is favored by the whole community, because the aroma and flavor often make coffee lovers feel addicted. Coffee contains many antioxidants that can inhibit diseases caused by oxidative damage. ${ }^{1}$ Bioactive components of coffee beans such as flavonoids, xanthine, antioxidants, alkaloids, polyphenols have been known to function as immunomodulators, anti-inflammatory, antibacterial agents also affect platelet aggregation. The bioavailability ability of coffee polyphenols has also been investigated. The antioxidant activity of roasted coffee residues has also been evaluated. Ethanol extracts coffee beans proved that antioxidants can sustain cells life.Coffee antioxidants can contribute a lot to the prevention or therapy of various diseases. Antioxidants have function to neutralize free radicals and prevent cell damage by donating hydrogen electrons to free radicals, so that the cells become stable. One of the causes of free radical formation is when the process of phagocytosis occurs. In here free radicals will cause damage of foreign bodies after phagolisosomes formed, so the cell will be damaged..$^{2-5}$ Therefore, antioxidant-rich coffee is expected to resist cell viability.
Analysis for viability parameters is very important, because it can determine the quality of the cell, so it will survive the attack of foreign objects. Viability can be determined by a variety of different methods, so methods that are most common with trypan blue staining.Cell-based examination is a major component in drug discovery, in which an ingredient is analyzed to assess the effect on cell viability, cell proliferation or show a direct cytotoxic effect that ultimately causes cell death. Assessing cell viability is a key step in manipulation cell at any time and is a major requirement for processing and analysis. Cell proliferation and characterization of chemicals that promote or inhibit cell proliferation are important parts of cell biology and for drug discovery. ${ }^{6,7}$ Cell viability is the cell's ability to defend itself from foreign bodies and restore its condition. Viability of these cells were expected could be maintained by coffee beans, because of the antioxidant content. Currently green coffee is more popular than black coffee, allegedly because of higher antioxidant content and lower caffeine. So, purposed this research is analyze viability of PBMC and salivary leucocytes by extract from 
green coffee and black coffee beans from Robusta coffee after induced with S. mutans. We used PBMC and salivary leukocytes because these cells were immunocompetent cells that against to S. mutans. Whereas that cells have receptors that can recognize S. mutans.

Several studies have proven that black coffee beans can prevent and treat dental caries. ${ }^{8,9}$ Previously we have examined the anti-inflammatory effects of black coffee beans on dental caries. However, no study has yet proven the effect of green coffee beans and the comparison between the two coffees. ${ }^{10,11}$ Previously conducted an Ethical Clearance test at the Faculty of Dentistry (No. 078/ UN25.8/KEPK/DL/2018).

\section{Material and Methods}

Venous blood vessels in the subject of $6 \mathrm{cc}$ and then divided into 2 tubes with the amount of each $3 \mathrm{cc}$ on tube heparin. Each blood Coated $3 \mathrm{ml}$ of Histopaque-1077 (Sigma) on the falcon, superimposing $6 \mathrm{ml}$ of blood above it carefully, then sentrifuge $\left(1900 \mathrm{rpm}\right.$ for 30 minutes at $\left.26^{\circ} \mathrm{C}\right)$. Blood Formed 6 layers, mononuclear are in the $2^{\text {nd }}$ layer,then place it in the falcon tube. Added HBSS (Hank's Balanced Salt Solution/Gibco) 1:1 and pipeting, centrifugation (1700 rpm for 10 minutes at $\left.26^{\circ} \mathrm{C}\right)$. Discard the supernatant and residue deposits, add 2 cc HBSS. Mononuclear added fungizone

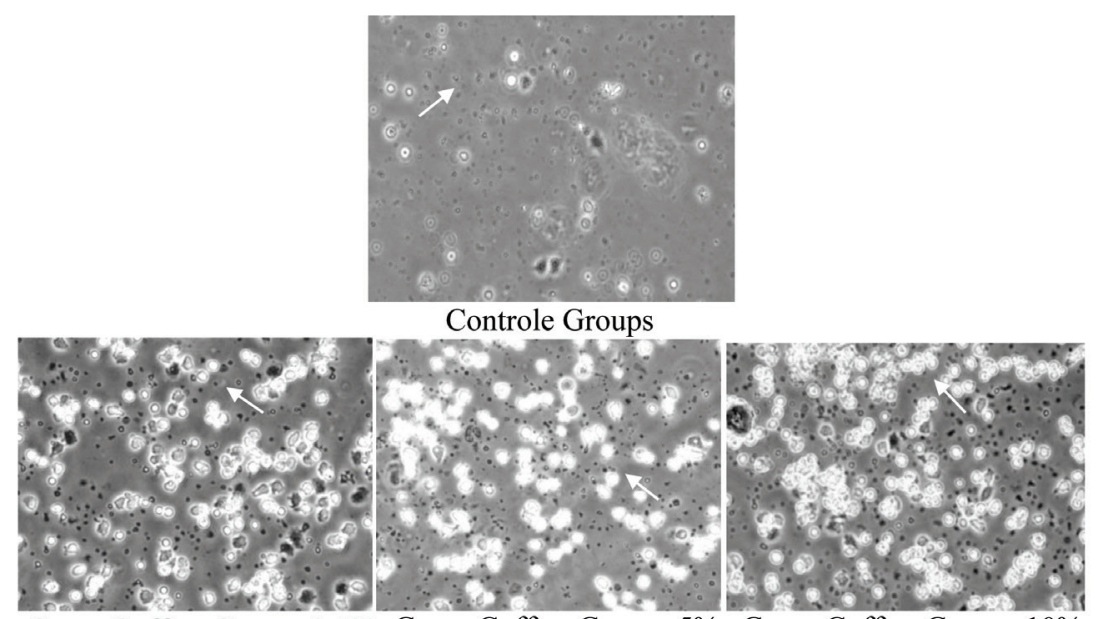

Green Coffee Groups 2,5\% Green Coffee Groups 5\% Green Coffee Groups 10\%

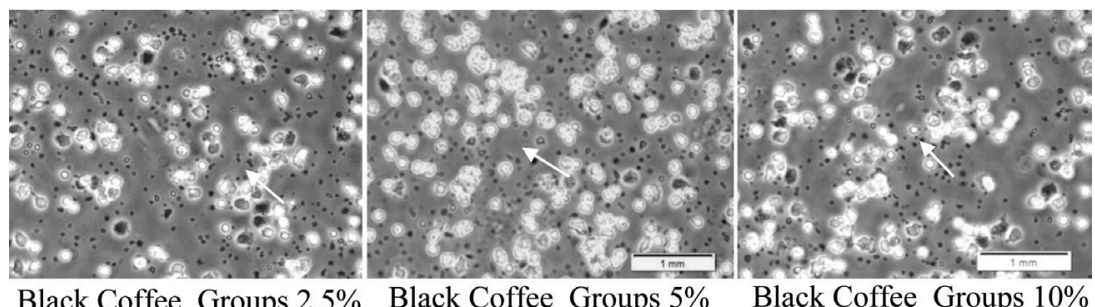

Black Coffee Groups 2,5\% Black Coffee Groups 5\% Black Coffee Groups 10\%

Figure 1 Viability of PBMC by green and black Robusta coffee that exposed by $\mathrm{S}$. mutans.
$5 \mu \mathrm{L}$ and penstripe $20 \mu \mathrm{L}$ per $1 \mathrm{cc}$, pipeting then insert mononuclear at each well @ $100 \mu \mathrm{L}$, incubate (15 minutes). The mononuclear was superimposed on each coverslip (@100 $\mu \mathrm{L}$ ) and placed in 24 microplate, then incubated (15 minutes). Add RPMI (Sigma) $1 \mathrm{cc}$ at each well, $20 \mu \mathrm{L}$ penstripe and $5 \mu \mathrm{L}$ fungizone, incubate 20 minutes). Perform $2 x$ leaching until there was no contamination. The trick was that the liquid was taken with a pipette and then discarded, add RPMI at each well then washed again. If there was no contamination add media complete, added the coffee with the required concentration. Giving steeping at each concentration of $200 \mu \mathrm{L}$. For the control group only given medium complete. Incubate for 3.5 hours when no contamination was exposed to $\mathrm{S}$. mutans of $100 \mu \mathrm{L}$, incubation for 5 hours. Dispose of incubation medium and cell washed $1 \mathrm{x}$ with HBSS, fixation with absolute methanol 1 minute. Dispose of methanol with micropipet then dried in a tilted position. The next stage was stained with Tripan Blue.

$5 \mathrm{ml}$ of saliva was collected from healthy people in $50 \mathrm{ml}$ sterile Falcon tubes placed on ice. Saliva was added with HBSS, then filtered with nylon mess 20. Saliva coated with $3 \mathrm{ml}$ Histopaque 1077 (Sigma), superimposing saliva above it carefully. Sentrifuge $\left(1700 \mathrm{rpm}\right.$ for 10 minutes at $\left.4^{\circ} \mathrm{C}\right)$, a white ring will form, so leucocytes were taken from the white ring, then placed in falcon tube. Added 1:1 and pipeting, centrifugation (1700 rpm for 10 minutes at $4^{\circ} \mathrm{C}$ ). The next procedure is the same as in PBMC.

The Observe of viabilityhas been done with an inverted microscope (400x magnification) from an average of 5 fields of view, it were observed luminous cells (white). The data obtained were analyzed using ANOVA followed by LSD test.

\section{Results}

The research has been done in the Laboratory of Bioscience Laboratory of Dental Hospital, Jember University. The results of this study has been seen as a description of PBMC cells and salivary leucocytes which can be seen in figures 1 and figures 2, showing differences in each research groups figures 3 and figure 4 . White cells showed that the cells live (400X magnification with a light microscope).

Anova analysis and LSD test showed significant differences between groups $(\mathrm{p}<0.01)$. Various concentrations of Robusta coffee beans steeping improved toPBMCand salivary leukocytes viability. The higher the concentration of coffee beans, the more living cells (increased viability). While the comparison between the Black Coffee and Green 


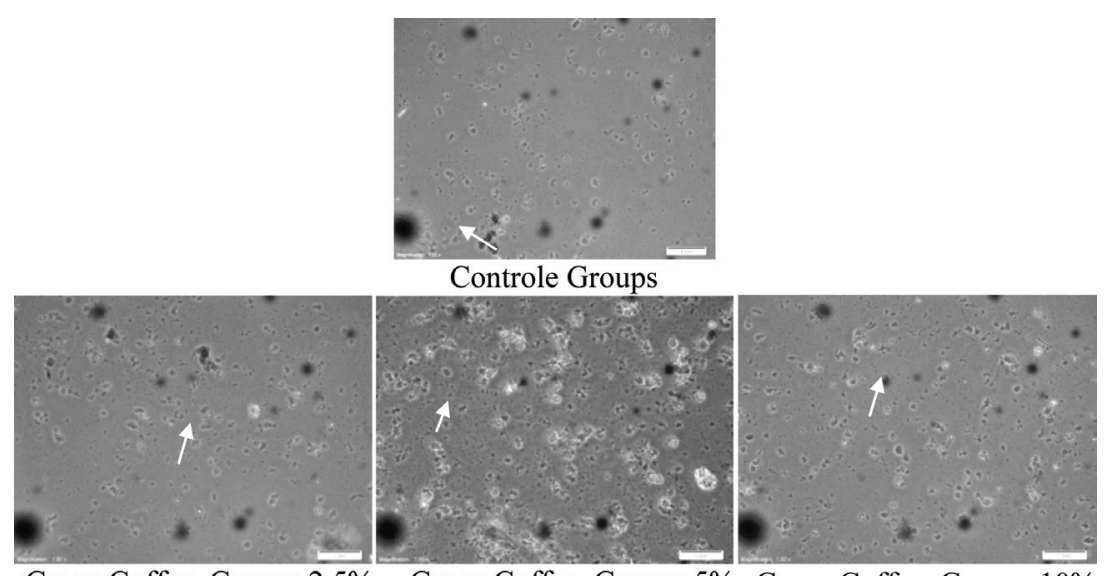

Green Coffee Groups 2,5\% Green Coffee Groups 5\% Green Coffee Groups 10\%
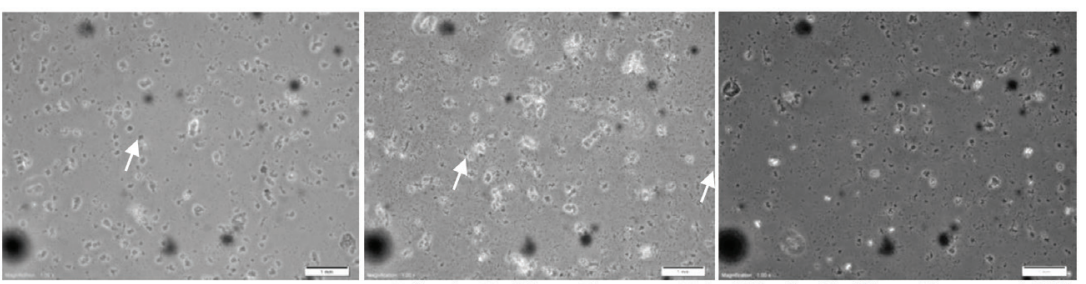

Black Coffee Groups 2,5\% Black Coffee Groups 5\% Black Coffee Groups 10\%

Figure 2 Viability of Salivary leukocytes by green and black Robusta coffee that exposed by S. mutans.

Viability of PBMC

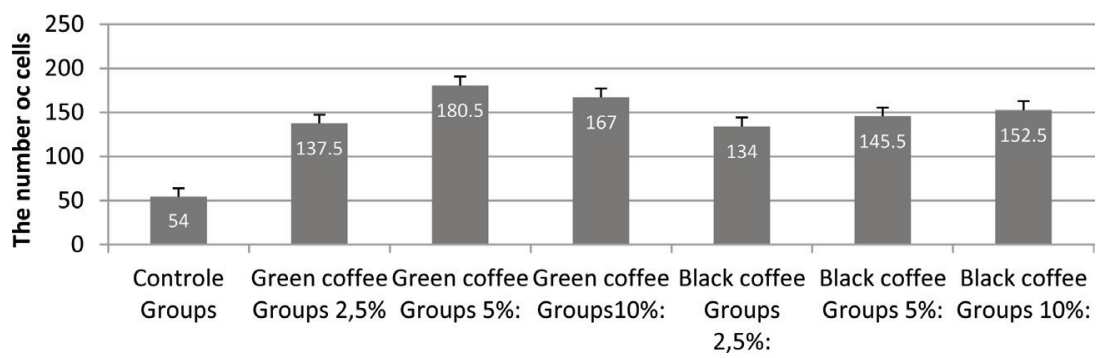

Figure 3 Diagram of Viability of PBMC by green and black Robusta coffeethat exposed by S. Mutans

\section{Viability of Salivary Leukocytes}

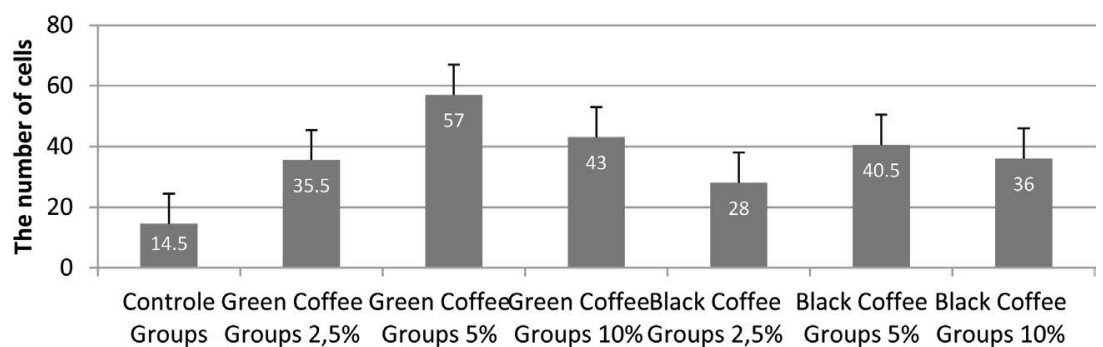

Figure 4 Diagram of Viability of Salivary leukocytes by green and black Robusta coffeethat exposed by S. mutans

Coffee groups, shows that Green Coffee increase cells viability more than Black coffee.

\section{Discussion}

In this study it was proved that Robusta coffee beans can improve the viability of PBMCand salivary leukocytes exposed by S. mutans. It was suspected that Robusta coffee beans had bioactive contents which made PBMC and salivary leukocytes survive even though there were microorganisms. The content is thought to be antioxidants (polyphenol, chlorogenic acids). Phenolic or polyphenolic compounds which can be in the form of flavonoids. The flavonoids which have antioxidant activity include flavones, flavonols, isoflavones, flavonols. While derivatives of cinnamic acid which act as antioxidants include caffeic acid, ferulic acid, chlorogenic acid. Recent studies from the University of Scaranton prove that coffee ranks first as a source of antioxidants. This antioxidant is also found in the aroma of coffee. Chlorogenic acid is an ester which is composed of essential ingredients and asphaltic acid. During roasting chlorogenic acid will synthesize with proteins and polyphenol compounds form melanoidin. Robusta coffee beans have greater chlorogenic acid than Arabica coffee. ${ }^{12-16}$ Antioxidants (caffeic acid, chlorogenic acid, coumaric acid, sinapat acid, chlorogenic acid, flavonoids, melanoidin, faran, pitol and maltol) immediately react with free radicals and will form stable molecules. ${ }^{17,18}$

These antioxidants will maintain cell integrity from free radical damage. Free radicals (ROS / Reactive Oxigen Species) can cause destruction of electron-deficient cell molecules, namely macro molecules such as proteins, carbohydrates, fats, DNA. On the other hand the components of cell membranes (polyunsaturated fatty acids) are very susceptible to these free radical attacks. ${ }^{14}$ Hydrophilic antioxidants, especially phenolic components, work easilyin donating one hydrogen atom to ROO•. Flavonoids are the most effective compounds as scavanger reactive species, such as super dioxide, peroxyl radicals, and peroxinitrite by transferring $\mathrm{H}+$ atoms. Prevention is formedFlavonoid ROS is done in several ways, namely inhibiting the action of the xanthine oxidase enzyme and Nicotinamide Adenine Dinucleotide Phosphate (NADPH) oxidase, and chelating the metal $(\mathrm{Fe} 2+$ and $\mathrm{Cu} 2+)$ so as to prevent redox reactions that can produce free radicals,flavonoids are antioxidants that play a role in protecting antioxidantslipophilic so that it can strengthen cellular antioxidants. ${ }^{15-23}$

The group controle showed many PBMC and salivary leukocytes lysis, it caused by the effects of free radicals, such as NO. The antioxidant content is thought to work through suppression of NO (Nitric Oxide) production. The formation of NO in large quantities will certainly be potentially cytotoxic, so that it can injure the cells and surrounding tissue either by itself or with the 
formation of ONOO-. Antioxidant mechanism of suppression can go through several possibilities. First, it may inhibit the action of the cytokine-induced NO synthase enzyme (iNOS) by controlling iNOS mRNA. Another possibility is to inhibit arginine transport through the mechanism of controlling CAT-2 mRNA (Cationic Amino Acid Transporter-2 mRNA). This can occur due to suspected damage to PBMC damage due to the effects of NO free radicals. Usually NO can be produced by cells exposed to pathogens, which are caused by the formation of various cytokines and endotoxins of pathogenic bacteria that are damaging to cells. As a pathogen attack, $\mathrm{NO}$ will be synthesized in large quantities. NO, which is synthesized in large amounts will cause malfunctioning and cell proliferation (cytostatic). In addition to flavonoids and phenolics as antioxidants, other studies also report that mechanisms such as $\mathrm{Cu}, \mathrm{Zn}, \mathrm{Mg}, \mathrm{Mn}$ and Se perform significant functions in antioxidant systems. The content of natural antioxidants is certainly free from side effects, and is cheaper. Natural antioxidants that are used can prevent harmful effects and therefore antioxidants are one of the more important therapeutic forms for diseases triggered by oxidative stress. Besides having antioxidant activity, flavonoids and phenolic compounds also have an effective role as an anti-inflammatory factor. Chlorogenic acid is another well-known efficient antioxidant in coffee extracts; especially in roasted coffee extract. But the concentration of antioxidants is also influenced by the length of roasting, because it will affect the antioxidant properties of coffee extracts and biological antioxidant properties in cells.Chemical analysis proves that green coffee contains higher chlorogenic acid than roasted coffee. ${ }^{19,24-26}$

\section{Conclusion}

This research can be concluded that steeping Green and black coffee increase viability of PBMC and salivary leukocytes which is induced by S. mutans. From this study it was also proven that Robusta green coffee steeping is stronger to improve the viability of PBMC and salivary leukocytes than Robusta black coffee.

\section{Acknowledgment}

Authors are also grateful to RISTEKDIKTI was funded this research, and we are also grateful to the Chair of University of Jember LP2M for recommending this research.

\section{Conflict of Interest}

The authors report no conflict of interest.

\section{References}

1. Editorial Health Secret. Efficacy of Bombastic coffee. Jakarta: PT Elex Media Komputindo; 2010. p.4-6.

2. Coralie JD, Agnès CMB, Claire SO, et al. Coffee antioxidant properties: effects of milk addition and processing conditions. J Food Sci2006;71: S253-S258.

3. Natella F, Nardini M, Belelli F, et al. Effect of coffee drinking on platelets: inhibition of aggregation and incorporation phenols. Br J Nutr2008;100: 1276-1282.

4. Scalbert A,Gary W. Dietary Intake and Bioavailability of Polyphenols. J Nutr 2000;130: 2073S-2085S.

5. Alexander Y, YakovY, Jing YW, et al. Antioxidant and antiradical activity of coffee. Antioxidants (Basel) 2013;2:230-245.

6. Magdalena KM, Renata ZT. Comparison of methods used for assessing the viability and vitality of yeast cells. FEMS Yeast Res2014;14: 1068-1079.

7. Andrew S, Henry B, Bryony JT. A comparison of real-time and endpoint cell viability assays for improved synthetic lethal drug validation. J Biomolec Screening 2015;20: 1286-1293.

8. PC-Anila N, Sumathi K. Can coffee prevent caries?.J Conserv Dent2009;12:17-21.

9. Namboodiripad PK. Srividya: can coffee prevent caries? an in-vitro study. J Dent Sci2009;7: 17-21.

10. Zampelas A,PanagiotakosDB,PitsavosC,et al.Associations between coffee consumption and inflammatory markers in healthy persons: the ATTICA study. Am J Clin Nutr 2004;80:862-867.

11. Choi S, Jung S, Ko KS. Effects of coffee extracts with different roasting degrees on antioxidant and anti-inflammatory systems in mice. Nutrients 2018;10:363.

12. Samar AA, Khitma AS,Amro BH. Estimation of phenolic and flavonoid compounds and antioxidant activity of spent coffee and black tea (processing) waste for potential recovery and reuse in sudan. Recycling 2018;3:2-9.

13. Badria AF, El-Belbasi HI, Sobh MM, et al. Parallelism study between biochemical, immunological and histochemical parameters of liver injury induced by carbon tetrachloride on rats. J American Sci2011;7: 581-591.

14. Hanani E, Mun'im A, Sekarini R.Identifikasi Senyawa Antioksi dan dalam Spons Callyspongia sp. Dari Kepulauan Seribu. Majalah Ilmu Kefarmasian2005;2: 127-133.

15. Lotito SB, Fraga CG. Catechins delay lipid oxidation and alpha-tocopherol and beta-carotene depletion following ascorbate depletion in human plasma. Proceeding of the Society for Experimental Biolo\& Med 2000;225: 32-38.

16. Middleton E Jr, Kandaswami C, Theoharides TC. The effects of plant flavonoids on mammalian cells: implications for inflammation, heartdisease and cancer. Pharmacol Rev 2000;52: 673-751.

17. Hecinovic I, Cvitanovic AB, Horzic D, et al. Comparation study of polyphenols and caffein in different coffee varietas affected by the degree of roasting. Foof Chemistry 2011;129: 91-1000.

18. Castelnovo $\mathrm{AD}$, Giuseppe $\mathrm{RD}$, Lacoviello $\mathrm{L}$, et al. Consumption of cocoa, tea and coffee and risk cardiovascular disease. EuroJ Inter Med 2012;23: 15-25.

19. JaehakL,KandhasamyS, MihaeK,et al. Antioxidant, inhibition of $\alpha$-glucosidase and suppression of nitric oxide production in LPS-induced murine macrophages by different fractions of Actinidiaargutastem. Saudi J BioloSci 2014;21: 532-538.

20. Wen-Fei C, Chieh-Fu C, Jin-Jung L.Mechanisms of suppression of inducible nitric oxide synthase (iNOS) expression in RAW 264.7 cells by andrographolide. $\mathrm{Br}$ J Pharmacol 2000;129: 1553-1560. 
21. Soohan J, Min HK,Jae HP, et al. Cellular antioxidant and anti-inflammatory effects of coffee extracts with different roasting levels. J Medic Food2017;20: 3935.

22. Wen-JyeY, Bor-SenW, Lee-Wen C, et al. Antioxidant properties of roasted coffee residues. J Agric Food Chem 2005;53: 2658-2663.

23. Gayathri G, Neelima M,Balabhaskar R. In vitro antioxidant analysis of selected coffee bean varieties. J Chemic \&Pharmaceutic Res 2012;4:2126-2132.

24. BruceC, YatesDH, ThomasPS. Caffeine decreases exhaled nitric oxide. Thorax 2002;57:361-363.

25. Ji HJ, Hee RJ,Yu NJ, et al. Antioxidant and neuronal cell protective effects of columbia arabica coffee with different roasting conditions. Prev Nutr Food Sci 2013;18: 30-37.
26. Regina CLA, Ana PLV, SimoneF, et al. Phytochemical composition, antioxidant activity, and the effect of the aqueous extract of coffee (coffea arabica L.) bean residual press cake on the skin wound healing. Oxid Med Cell Longev 2016;2016: 1923754 .

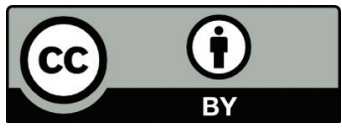

This work is licensed under a Creative Commons Attribution 